\title{
Assertiveness and Empathy Toward Prosocial Behatior
}

\author{
Lisbet Situmorang ${ }^{1} 8 D \square$, As'liyanti Nor ${ }^{2}(D)$, Karenina Amanda Stephanie Pattinasarany ${ }^{3}$ (D), Stevent \\ Resma $^{4}$ 8 $(0)$ and Andi Aulia ${ }^{5}$ (D) \\ ${ }^{12345}$ Faculty of Social and Political Sciences, Mulawarman University, Indonesia
}

$\triangle$ Corresponding Author: Lisbet Situmorang, E-mail: lisbetsitumorang14@gmail.com

\section{ARTICLE INFORMATION ABSTRACT}

Received: August 08, 2021

Accepted: September 14, 2021

Volume: 3

Issue: 9

DOI: 10.32996/jhsss.2021.3.9.1

\section{KEYWORDS}

Crimes; socio-economic factors; economic growth; correlation; regression
This study aims to determine the effect of assertiveness and empathy on students' prosocial behavior at the Faculty of Social and Political Sciences, Mulawarman University. This study uses quantitative methods using multiple regression analysis to determine how much influence and predictive ability the two independent variables have on the dependent variable. In this study, the subjects in this study were 100 students of the Faculty of Social and Political Sciences, Mulawarman University, using the accidental sampling method. Data collection methods used include assertiveness, empathy, and prosocial behavior scales. The collected data were analyzed with the help of SPSS 21.0 for the windows program. These results indicate a significant difference between assertiveness and empathy to prosocial behavior.

\section{Introduction}

Humans are social creatures who live in society. Where humans always live side by side with other humans. Because humans cannot stand alone without the help of other humans, in everyday life, individuals help each other. Such as helping other people who are having trouble on the road, so when other people see the incident, as social beings, individuals should help people who need help even though they do not know each other.

Not only on the street, in the neighborhood too, but individuals must also be more caring and sensitive in order to be well received by the community. One of the layers in society is early adulthood. Early adulthood is included in the category of the transition period between adolescence and adulthood. According to Arnett (in Upton, 2012), adolescence and adulthood are also called the period of preparation (emerging adulthood), around 18 to 25 years. This stage can be classified in late adolescence to early adulthood. In terms of development, the developmental task of students is the establishment of life establishments (Yusuf in Huluki and Djibran, 2018).

The emergence of modernization and globalization today has a significant impact on human life, resulting in a shift in interaction patterns between individuals and other individuals and changes in values in social life. The interaction between individuals is reduced, and the social contacts that occur are of lower quality and quantity.

One form of shifting in the pattern of relationships between individuals and other individuals in the surrounding environment is the depletion of prosocial behavior in society. According to Baron and Byrne (in Muryadi and Matulessy, 2012, prosocial behavior), it is voluntary to help others without getting rewarded. Those who provide help feel satisfied after helping.

Prosocial behavior has a unique characteristic that puts the interests of others above personal interests. Welfare and benefit of people or groups is the goal of prosocial behavior. Muryadi dam Matulessy (2012) says that prosocial behavior includes three aspects, namely, actions that are carried out voluntarily, actions were taken are shown for the benefit of other people or a group of other people, and the action as a goal but not as a tool to satisfy personal motives.

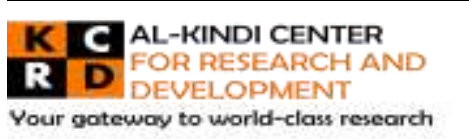

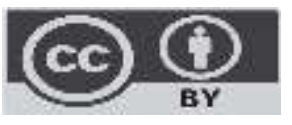

Published by Al-Kindi Center for Research and Development. Copyright (c) the author(s). This open access article is distributed under a Creative Commons Attribution (CC-BY) 4.0 license 
Prosocial behavior is not only carried out by the community but also by students. Because students are part of the community, students must also play an active role in the community or their environment (Sarwono, 2012). From this identity, students have a role in society, both social responsibility, intellectual responsibility, and moral responsibility in their environment.

Based on data from the ministry of research, technology, and higher education (2018), 6,951,124 students were registered at 3,293 universities spread across Indonesia. Through these data, especially in East Kalimantan, there are 51 private universities and five state universities. One of the most popular public universities in East Kalimantan, Mulawarman University, is a state university.

Mulawarman University was founded on September 27, 1962, located in the city of Samarinda, the capital of East Kalimantan. Mulawarman University has 12 faculties; each faculty has a unique calling in naming its faculty. One of them is the Faculty of Social and Political Sciences, known as the struggling campus. Students are considered as young intellectual candidates who are undergoing a learning process demanded by the community to have a responsibility to behave in society. However, many students are still not aware of the importance of prosocial behavior in society.

This is supported by the phenomenon of prosocial behavior in students that cannot always be found in everyday life on campus. Based on the results of Cahyono's observation (2016) which states that even if there is prosocial behavior in students, it will still be sporadic. For example, they littered in the campus area, were indifferent when a friend fell, and disturbed. What is often seen is students' "conditioning of prosocial behavior" through community service activities, social services, and assignments when they are new students. This means that students "must be forced" to behave prosocially, hoping that they will be motivated to care for others while they are students.

The above study results indicate that several factors influence prosocial behavior, where students will act more prosocially when there are vital motivating factors. According to Taylor, Peplau, and Sears (2012), prosocial behavior can be influenced by several factors, namely mood or feelings, personal empathy and sadness, gender, and the presence of other people (bystander). This was expressed by Cahyono (2016), who states that students feel that they are not by the life values they believe in, so prosocial behavior will not be taken.

According to Taylor, Peplau, and Sears (2012), prosocial behavior can be influenced by several factors that influence prosocial behaviour, namely mood or feelings, personal empathy and sadness, gender, and the presence of other people (bystander). According to Rathus and Nevid (in Retiara, Khairani, and Yulandari, 2016), this opinion aligns with the factors that affect assertiveness, namely gender, self-esteem, social and cultural conditions, education level, personality type, certain situations around them, and patterns of behavior. It can be seen the relationship between factors that affect assertiveness and factors that influence prosocial behavior. In gender, men are more assertive, so they are faster to make decisions.

This is supported by a phenomenon that explains that other people (bystanders) and certain situations around it also influence, wherein behavior allows a person to see conditions and situations in a broad sense. According to Crisp and Turner (in Hadori, 2014), bystanders and situations are essential to consider in helping others. Because not always all situations can be used to help. Many studies and theories state that help is usually done when the situation is very pressing or emergency.

This is the same as the results of experimental research conducted by Mercer and Clayton (2012), which involved male students faced with a situation where there were students (as experimental assistants) who experienced convulsions and shortness of breath. In this experiment, they tested students. They heard there was an emergency in the next room. Students chose not to respond because there were more people than students alone. This proves that prosocial behavior can be viewed from the bystander effect.

The experiment results showed that the number of sanctions affected the provision of assistance because students who heard of an emergency were more likely to react alone than in a crowded situation. The more observers at the scene, the longer it takes to respond. The less likely the individual will act, the more the bystander effect affects a person's prosocial behavior. The more the number of present bystanders lowers the number of people helping.

This is also by the opinion given by the subject DS (Male, 20 years) revealed in an interview conducted on March 22, 2020, at 20:45 that he will only help if he wants to or wait until someone else is there. Help first, or else he will ask his other friends to help the person. He will also help if he can help the person, or he happens to be there.

Prosocial behavior is behavior to help others. Prosocial behavior is related to positive behavior, social emotions, and individual psychology. Among the forms of prosocial behavior, empathy is directly related to prosocial behavior, and empathy plays a vital role in shaping prosocial behavior. Empathy is a factor within a person that cannot be made up and formed based on experience. With this experience, a person can move when he sees a situation that touches his conscience and needs his help, with one example being prosocial behavior (Puspita and Gumelar, 2014). 
According to Gustini (2017), empathy is an individual's ability to place oneself in the thoughts and feelings of others without having to be involved in that person's feelings or responses. This is per the research results by Asih and Pratiwi (2010), which states a positive relationship between empathy, maturity, emotions, gender, to behavior prosocial. Emotional maturity towards prosocial behavior $r x y=0.794$ and $p=0.000$. Emotional maturity is defined as the individual's ability to provide emotional response well in the face of a challenge and complete it (Asih and Pratiwi, 2010). These results are supported by Eisenberg, Beadle, and Sze (in Umayah, Ariyanto, and Yustisia 2012), which states that there is an effect of the relationship between empathy and prosocial behavior. This means, significantly individuals who have high emotional empathy scores have a high level of prosocial behavior.

Based on the results of initial interviews with several Faculty of Social and Political Sciences subjects, the researcher sees that prosocial behavior is strongly influenced by the empathy and assertiveness of the students. So, based on the series of problems described above, the authors are interested in researching with the title "The Effect of Assertiveness and Empathy on Prosocial Behavior" on students of the Faculty of Social and Political Sciences at Mulawarman University, Samarinda.

\section{Theoretical Basis}

According to Bashori (2017), prosocial behavior is nothing but the behavior of providing benefits to others by helping to relieve their physical or psychological burden, which is done voluntarily. Prosocial behavior is shown by aspects of prosocial behavior proposed by Widyastuti and Yeni (2014), which include: the presence of other people, environmental conditions and physical condition of the helper, limitations, and characteristics of the person helping.

According to Anfajaya and Indrawati (2017), assertive behavior is the ability to convey what they want, think, and feel to others honestly and openly while respecting the personal rights of that person. Assertiveness shown includes: acting by his wishes, being able to express honest feelings and uncomfortable, unable to defend themselves, were able to express their opinions, and does not waive the rights of others (Alberti and Emmons, 2016).

Gustini (2017) explained that empathy is an individual's ability to place oneself in the thoughts and feelings of others without having to be involved in that person's feelings or responses. Empathy can be shown by aspects of empathy proposed by (Davis 2012): perspective taking, fantasy, empathic anxiety, and personal pressure.

According to Taylor, Peplau, and Sears (2012), prosocial behavior can be influenced by several factors: mood or feelings, gender, presence of other people (bystander), empathy, and personal sadness. Other people (bystanders) and certain situations around them also influence, wherein prosocial behavior, a person, will see conditions and situations in a broad sense. There is an error in assuming that assertive behavior is an attempt to help others, whereas someone who feels unable to refuse other people's requests considers that behaviour an attempt to help others (Rathus and Nevid in Retiara, Khairani, \& Yulandari, 2016).

This is the same as the results of experimental research conducted by Latane and Darley (in Fahmi, 2017); they say that the presence of many people may cause a lack of help. In the experiment testing the students, they heard an emergency in the next room, but the students chose not to respond because more people were there than the students alone; this proves that prosocial behavior can be viewed from the bystander effect.

Carlo and Walker (2014), in their research, found that prosocial behavior is one of the virtues that need to be built, and this is also part of the aspect that affects assertiveness (Galassi in Susilawati, 2016) a person's behavior that is driven by the belief that that person feels equal and has had the same fundamental rights, are free to think with their own decisions, can try something, are responsible for their actions and responses to others, and do not make any disagreements or differences with others.

Prosocial behavior is behavior to help others. Prosocial behavior is related to positive behavior, social emotions, and individual psychology. Among the forms of prosocial behavior, empathy is directly related to prosocial behavior, and empathy plays a vital role in shaping prosocial behavior. Empathy is a factor that exists within a person that cannot be made up and is formed based on experience. With this experience, a person can move when he sees a situation that touches his conscience and needs his help, with one example being prosocial behavior (Puspita \& Gumelar, 2014).

This is also explained by Goleman's (2016) aspects of empathy, namely caring. In this case, it can be concluded that individuals with a high level of empathy tend to want to do something to help others get out of their suffering. With empathy, a person will be more social, more forgiving, work together, and interact with other individuals. Someone can carry out prosocial behavior if they have sympathetic characters (Ni'mah, 2017). These results are supported by Aknin, Dunn, and Norton (2012) which state that positive effect plays a more critical role in generating prosocial behavior. Based on the description above, it can be concluded that the framework of thinking in this study is as follows: 


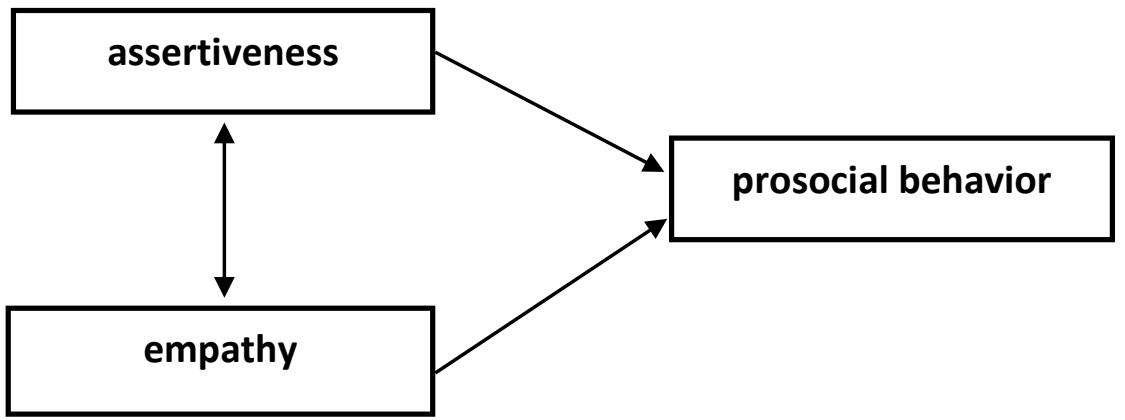

Figure 1. The conceptual framework for research

$\mathrm{H}_{1}$ : There is an influence between assertiveness and empathy on students' prosocial behavior of the Faculty of Social and Political Sciences, Mulawarman University.

$\mathrm{H}_{2}$ : There is an influence between assertiveness on prosocial behavior in students of the Faculty of Social and Political Sciences, University Mulawarman.

$\mathrm{H}_{3}$ : There is an effect of empathy on prosocial behavior in students of the Faculty of Social and Political Sciences, University Mulawarman.

\section{Research Method}

The research method used in this research is using quantitative methods. With the dependent variable, prosocial behavior, and independent variables, namely, assertiveness and empathy. In this study, the sampling technique used is non-probability sampling. Non-Probability sampling is a sampling technique in which members of the population do not have the same opportunity to become members of the sample (Sugiyono, 2015). Sampling technique Non-Probability Sampling researchers used the accidental sampling method (accidental sampling).

According to Santoso \& Tjiptono (2001), accidental sampling (convenience sampling) is a sampling procedure that selects samples from people or units that are easiest to find or access. Meanwhile, according to Sugiyono (2015), accidental sampling takes respondents as samples based on chance; anyone who coincidentally meets a researcher can be used as a sample if the person who happens to be met is suitable for data source with the main criteria.

So that in this study, the number of samples used as research was 100 students of the Faculty of Social and Political Sciences, Mulawarman University. The researcher did this because the researcher could not take all the data on the research subject and facilitate the researcher in determining the sample. The method of data collection in this study uses measurement tools or instruments. There are three research instruments used, namely the scale of prosocial behavior, assertiveness, and empathy. This study uses a Likert-type scale. The Likert scale is used to measure the attitudes, opinions, and views of a person or group of people about social phenomena (Sugiyono, 2016). The scale is processed using a Likert form with five alternative answers and grouped into favourable and unfavourable statements.

The data processing process begins with testing the validity and reliability of each variable scale in this study. On the prosocial behavior scale, two items fall out of 46 items with a reliability value of 0.929 . Assertiveness scale, three items fail with a reliability value of 0.300 . For the empathy scale, there are no items that fall out of 24 items with a reliability value of 0.897 . The data analysis technique used is multiple regression analysis, and a hypothesis analysis test is carried out, preceded by an assumption test. All data analysis techniques were processed with the help of SPSS (computer program statistical Packages for Social Science) version 21.0 for Windows.

\section{Research Result and Discussion}

\subsection{Research Results}

Descriptive data is used to describe data distribution among students of the Faculty of Social and Political Sciences, Mulawarman University. The empirical mean and hypothetical mean were obtained from the responses of the research samples through three research scales, namely the prosocial behavior scale, assertiveness scale, and empathy scale. 
Table 1:Mean Empirical and hypothetical

\begin{tabular}{llll}
\hline \multicolumn{1}{c}{ Variable } & Mean Empirical & Mean hypothetical & Status \\
\hline Prosocial Behavior of & 178.37 & 132 & High \\
Assertiveness & 63.15 & 63 & High \\
Empathy & 95.17 & 72 & High \\
\hline
\end{tabular}

Through Table 1 above, we can see the general picture of the distribution of data on the subject of the research students of the Faculty of Social and Political Sciences Mulawarman University. Based on the results of the measurement of the prosocial behavior scale, the empirical average is 178.37, which is higher than the hypothetical average in the advanced category of 132 in the high category. This proves that the research subject is included in the high category, namely prosocial behavior.

Based on the measurement results of the filled assertiveness scale, the empirical average is 63.15 higher than the hypothetical average of 63 with a higher category. This proves that the research variable is included in the category of high assertiveness on the subject. Based on the measurement results through the empathy scale that has been filled in, the mean is empirical 95.17, which is higher than the mean of hypothetical 72 in the high category. This proves that the research subjects are in the category of high empathy.

Before analyzing the data in hypothesis testing, it is necessary to test assumptions consisting of normality tests and linearity tests. The results of the research data assumption test are as follows:

Normality test is to observe the deviation of the observation frequency from the theoretical frequency. The normality test of the data can be done by comparing the probability of the Kolmogorov-Smirnov value with 0.05 ( $5 \%$ ). The rule used is if $p>0.05$, then the distribution is normal; otherwise, if $p<0.05$, then the distribution is not normal. (Santoso, 2012).

Table 2: Normality Test Results

\begin{tabular}{lccc}
\hline \multicolumn{1}{c}{ Variable } & Z & P & Description \\
\hline Prosocial Behavior & 0.061 & 0.200 & Normal \\
Assertiveness & 0.069 & 0.200 & Normal \\
Empathy & 0.104 & 0.009 & Abnormal \\
\hline
\end{tabular}

Based on the normality test results that has been carried out on each variable, it is found that the p-value of the prosocial behavior and assertiveness variables $>0.05$ means that both variables have a normal distribution of data. The result is that the $p$ value of the empathy variable is $<0.05$, which means that the empathy variable has an abnormal data distribution.

Testing the linearity assumption is carried out to determine the relationship between the dependent and independent variables. Linearity is a condition in which the relationship between the dependent variable and the independent variable is linear (straight line) within a range certain of independent variables (Santoso, 2012). The rule used in the linearity test is that if $p>0.05$ deviates from the linear value, and the calculated $\mathrm{F}$ value $<\mathrm{F}$ table is at a significance level of $5 \%$ or 0.05 , the relationship is declared linear (Gunawan, 2013).

Table 3: Linearity Test Result

\begin{tabular}{lllll}
\hline Variable & f-hit & f-tab & P & Ket \\
\hline Prosocial Behavior -Asertivitas & 1864 & $3: 09$ & 0031 & No Linear \\
Prosocial Behavior - Empathy & 0.425 & $3: 09$ & 0.996 & Linear \\
\hline
\end{tabular}

Based on the results in the table above shows that among variables, prosocial behavior and assertiveness do not have a linear relationship $(p>0.05)$ and shows that between variables, prosocial behavior and empathy have a linear relationship $(p<0.05)$. After testing the assumptions, then the hypothesis test of the multiple regression model analysis was carried out. The results of testing the full regression model based on the variables of assertiveness and empathy for prosocial behavior together obtained the following results: 
Table 4: Heteroscedasticity Test Results

\begin{tabular}{lcccc}
\hline Variable & T Count & T Table & $\mathbf{P}$ & Description \\
\hline Assertiveness & -0.963 & 1.984 & 0.338 & No Heteroscedasticity \\
Empathy & -1.104 & 1.984 & 0.272 & No Heteroscedasticity \\
\hline
\end{tabular}

The results of the heteroscedasticity test in table 27 above show no heteroscedasticity symptoms in the regression model in this study. The significance value obtained from testing with the Glejser method on the assertiveness and empathy variables obtained a value of more than 0.05 to the absolute residual (Abs_Res) partially and the $\mathrm{t}$ count $<\mathrm{t}$ table.

Table 5 : Model Regression Analysis Test Result

\begin{tabular}{lcccc}
\multicolumn{1}{c}{ Variable } & F-hit & F-tab & R2 & P \\
\hline $\begin{array}{l}\text { Prosocial Behavior }(\mathrm{Y}) \\
\text { Assertiveness (X1) }\end{array}$ & 145,096 & 3.09 & 0.749 & 0.000 \\
Empathy (X2) & & & & \\
\hline
\end{tabular}

Based on table 29 above, the results show that $\mathrm{F}$ count $>\mathrm{F}$ table, which means that assertiveness and empathy for prosocial behavior significantly influence $F=145,096, R^{2}=0.749$, and $P=0.000$. This means that the significant hypothesis in this study is accepted. Then from the results of the gradual regression analysis, it can be seen as follows:

Table 6 : Test Results in An Analysis of Gradual Regression Model

\begin{tabular}{|c|c|c|c|c|}
\hline Variable & Beta & t-hit & t-tab & $\mathbf{p}$ \\
\hline $\begin{array}{l}\text { Assertiveness (X1) } \\
\text { Prosocial Behavior (Y) }\end{array}$ & 0.060 & 1.177 & 1.984 & 0.242 \\
\hline $\begin{array}{l}\text { Empathy (X2) } \\
\text { Prosocial Behavior (Y) }\end{array}$ & 0.856 & 16,696 & 1,984 & 0.000 \\
\hline
\end{tabular}

Based on table 30 above, it can be seen that $\mathrm{t}$ count $<\mathrm{t}$ table shows that there is no significant effect between assertiveness on prosocial behavior with beta $=0.060$, $t$ count $=1.177$, and $p=0.242(p>0.05)$. Then the empathy towards prosocial behavior produces $t$ count $>t$ table which means there is a significant effect with beta $=0.856$, $t$ count $=16,696$, and $p=0.000(p<0.05)$.

\subsection{Discussion}

Can be seen from the first hypothesis, namely, is there an effect of assertiveness and empathy on prosocial behavior in students of the Faculty of Social and Political Sciences, Mulawarman University, starting from the class of 2016 to the class of 2020 . Based on table 5 . The results of the full model regression analysis test obtained show that $F$ count $>F$ table with $F=145,096$ and $p=$ $0.000(p<0.05)$. This shows that the major hypothesis in this study is accepted, which means assertiveness, and empathy for prosocial behavior have a significant influence.

The contribution of the influence (R2) of assertiveness and empathy to prosocial behavior is 0.749 . It indicates that 74.9 percent of the variation in prosocial behavior can be explained by assertiveness and empathy. Then the remaining 25.1 percent is explained by other variables or other reasons not examined in this study. According to Taylor, Peplau, and Sears (2012), in line with the factors that influence prosocial behavior. At the same time, other factors include mood or feeling personal empathy and sadness, gender, and other people's presence (bystander). Factors in this study included the factor of empathy and personal willingness. According to Taylor, Peplau, and Sears (2012), prosocial behavior includes a broader category, all forms of action that have been taken or planned to help others, regardless of one's motivation. By students who tend to be assertive and empathetic when they see other people need help student behavior can be influenced by peers around students because, in general, students tend to do what their friends do. Susilawati's (2016) opinion is that students can communicate with everyone openly, directly, honestly, and correctly, have an active view of life, have efforts to achieve what they want, and express their feelings. Moreover, in their mind able to give and receive praise and can accept their limitations. This means that the stronger the student's assertiveness, the lower the student's prosocial behavior. Conversely, the weaker the student's assertiveness, the higher the student's prosocial behavior. The influence of assertiveness on them and good empathy can trigger the emergence of prosocial behavior in students. 
By the results of research conducted by Carlo and Walker (2014), prosocial behavior is one of the virtues that need to be built, and this is also part of the aspects that affect assertiveness (Galassi in Susilawati, 2016) A person's behavior, the following beliefs drive this belief: a person feels that he is equal and has the same fundamental rights, can freely think in his own decisions, can try certain things, behave towards himself and others. Please take responsibility for their responses without questioning disagreements with others.

Based on the second hypothesis, namely whether assertiveness influences prosocial behavior in students, the results show no significant effect. According to Taylor et al. (2012), factors that influence prosocial behavior include mood, where a person performs helpful behavior when faced with a good mood. However, sometimes possible that people who are in a bad mood can still help others. Where assertiveness itself is a person's ability to express thoughts, feelings, and desires to others directly, honestly, openly, express them firmly, freely, and still respect others (Falentina \& Yulianti, 2012).

Prosocial behavior is nothing but the behavior of providing benefits to others by helping to relieve the burden both physically and psychologically, which is done voluntarily (Bashori, 2017). This is consistent with Susilawati (2016) statement that students have the attitude to communicate openly, directly, honestly and adequately with each person, have a positive outlook on life, trying to get what he wants, can express ideas and mind, being able to give and receive praise, and being able to accept your limits. This means that the stronger the student's self-confidence, the lower the student's prosocial behavior. Conversely, the weaker the student's assertiveness, the higher the student's prosocial behavior. Therefore, the influence of assertiveness and good empathy will trigger prosocial behavior in students.

The research results conducted by Carlo and Walker (2014) explain that prosocial behavior is one of the virtues that need to be built. This is also part of the aspects that affect assertiveness (Susilawati, 2016). A person's behavior is equal and has the same fundamental rights. They are free to think with their own decisions, try something, are responsible for their actions and responses to others, and do not mind their disagreements or differences.

In line with research conducted by researchers, the effect of assertiveness on prosocial behavior has a negative direction, meaning that the higher the assertiveness of the subject is affected by the surrounding environment. Meanwhile, if viewed from one of the factors that influence prosocial behavior, according to Taylor et al. (2012), other people are the presence of other people. Most people take action to help if there is intervention from people around them.

The third hypothesis, whether there is an influence of empathy on prosocial behavior in students and shows it has a significant effect. This means that the higher the empathy in a student, the higher the prosocial behavior of students and vice versa, lower the empathy in students and lower the student's prosocial behavior. Asih and Pratiwi's (2010) research results state a significant positive relationship between empathy, emotional maturity, gender, and prosocial behavior. His research shows that the higher the empathy, the better the prosocial behavior.

Any action that helps or is designed to help others, regardless of the helper's motives, is included in prosocial behavior (Widyastuti, 2014). Empathy will motivate someone to do beneficial actions and understand that others need more help to have fun after helping others. This explains that empathy is an essential factor influencing prosocial behavior. According to Taylor et al. (2012), the factors that cause a person to have prosocial behavior, namely feelings of sympathy and concern for others, or the ability of a person to be able to understand and appreciate the feelings of others by understanding feelings and emotions and looking at the situation from the perspective of others. So if students have empathy to understand and respect the feelings of others, they tend to have prosocial behavior. This means that if students have strong empathy, they will assist others without expecting certain things.

The results of this study are supported by previous research by Umayah et al. (2012), which showed a significant positive relationship between empathy and prosocial behavior of University of Indonesia students. More students have high empathy than students who have little empathy. Meanwhile, students with high prosocial behavior were more than students with low prosocial behavior.

Based on the descriptive test, it can be seen that the overall picture of the distribution of data on research subjects from the Faculty of Social and Political Sciences, Mulawarman University, shows that the research subjects are included in the categories of assertiveness, empathy, and high prosocial behavior. This shows that students of the Faculty of Social and Political Sciences, Mulawarman University, have high assertiveness, empathy, and prosocial behavior.

Based on the explanation above, it can be concluded that there is an effect of assertiveness and empathy on prosocial behavior in students of the Faculty of Social and Political Sciences, Mulawarman University, which is $74.9 \%$. In comparison, the remaining $25.1 \%$ is influenced by other variables not examined in this study. 


\section{Conclusion}

Based on the research that has been done, the following conclusions are obtained. First, there is a positive influence between assertiveness and empathy on prosocial behavior in students of the Faculty of Social and Political Sciences, Mulawarman University. Second, there is a positive and insignificant effect between assertiveness and prosocial behavior on students of the Faculty of Social and Political Sciences, Mulawarman University. Finally, there is a positive and significant effect between empathy with prosocial behavior in students of the Faculty of Social and Political Sciences, Mulawarman University.

Further researchers examine the factors that can influence prosocial behavior, considering that variables do not influence prosocial behavior, namely assertiveness. Future researchers are expected to find better findings from other studies. Research subjects are expected to maintain the empathy they have to carry out prosocial behavior, considering that prosocial behavior is a behavior that has a positive effect because it has aspects of sharing emotions, cooperation, donations, assistance, and honesty, and generosity. So that with empathy that can be maintained, it will make research subjects able to do good deeds from one form of prosocial behavior aspect.

\section{References}

[1] Asih, G. Y., \& Pratiwi, M. M. S. (2010). Perilaku prososial ditinjau dari empati dan kematangan emosi. Jurnal Psikologi Universitas Muria Kudus, 1(1), 33-42.

[2] Bashori, K. (2017). Menyemai perilaku prososial di sekolah. Jurnal Pendidikan, $\quad$ 1(1), 57-92.

[3] Cahyono, Y. B. (2016). Persepsi tentang metode service learning, konsep diri dan perilaku prososial mahasiswa. Jurnal Psikologi Indonesia, $5(2), 115-125$.

[4] Carlo, G., Laura, M., \& Walker, P. (2014). Prosocial development: a multidimensional approach. NY: Oxford University Press.

[5] Falentina, F. O., \& Yulianti, A. (2012). Asertivitas terhadap pengungkapan emosi marah pada remaja. Jurnal Psikologi, 8(1), 9-14.

[6] Gunawan, I. (2013) Metode penelitian kualitatif: Teori dan Praktik Jakarta: PT Bumi Aksara.

[7] Huluki, W., \& Djibran, R. M. (2018). Analisis tugas perkembangan mahasiswa fakultas ilmu Pendidikan universitas negeri Gorontalo. Jurnal Bikotetik, 2(1), 73-114.

[8] Muryadi \& Matulessy, A. (2012). Religiusitas, kecerdasan emosi dan perilaku prososial guru. Jurnal Psikologi, 7(2), 544-561.

[9] Puspita, R. S. D., \& Gumelar, G. (2014). Pengaruh empati terhadap perilaku prososial dalam berbagai ulang informasi atau retweet kegiatan sosial di jejaring sosial twitter. Jurnal Penelitian dan Pengukuran Psikologi, 3(1), 1-7.

[10] Retiara, G. S., Khairani, M., \& Yulandari, N. (2016). Asertivitas dan penyesuaian perkawinan pada dewasa awal di aceh tengah. Jurnal Psikogenesi, 4(2), 161-169.

[11] Santoso, S. (2012). Panduan lengkap SPSS versi 20. Jakarta: PT Elex Media Komputindo.

[12] Sarwono, S.W. (2012). Psikologi remaja. Jakarta: PT. Raja Grafindo Persada.

[13] Sugiyono, H. (2016). Metode Kualitatif dan Kuantitatif. Cetakan ke-23. Alfabeta, Bandung.

[14] Sugiyono. (2015). Metode Penelitian dan Pengembangan (Research and Development). Bandung: Alfabeta.

[15] Susilawati, D. (2016). Hubungan antara komunikasi interpersonal dan asertivitas terhadap perilaku seks pranikah pada remaja. Jurnal Psikologi Universitas Mulawarman, 4(4), 688-701.

[16] Taylor, S. E., Peplau, L. A., \& Sears, D. O. (2012). Social psychology 12th edition. Jakarta: Kencana Prenada Media Gnp.

[17] Umayah, A. N., Ariyanto, A., \& Yustisia, W. (2017). Pengaruh empati emosional terhadap perilaku prososial yang dimoderasi oleh jenis kelamin pada mahasiswa. Jurnal Psikologi Sosial, 15(2), 72-83.

[18] Upton, P. (2012). Psikologi perkembangan. Jakarta: Erlangga.

[19] Widyastuti, Yeni. (2014). Psikologi sosial. Yogyakarta: Fisip Untirta Press. 